\title{
FRAMEWORK OF AN AMBIDEXTROUS PROCESS OF IDEA MANAGEMENT SUPPORTING THE DOWNSTREAM PRODUCT DEVELOPMENT PROCESS
}

\author{
T. Herrmann ${ }^{\otimes}$, D. Roth and H. Binz \\ University of Stuttgart, Germany \\ $\square$ thorsten.herrmann@iktd.uni-stuttgart.de
}

\begin{abstract}
One challenge within idea management of the front end of the design process is the handling of radical ideas, meaning ideas with a high degree of novelty. Companies are approaching radical and incremental ideas frequently with the same methods, although many reasoned claims exists for treating ideas differently according to the degree of novelty. The paper aims to address the fact that ambidexterity does not play any specific role in the front end. Therefore, a framework of an extended idea process model based on the idea of ambidexterity is shown and initial test results are presented.
\end{abstract}

Keywords: innovation management, idea generation, process modelling, ambidexterity, radical innovation

\section{Introduction and motivation}

During the idea process (i.e., in the very early phases of product development), companies often face the particular challenge of generating, analyzing, and evaluating new product ideas, as well as deciding on the further progress (Messerle, 2012; Boeddrich, 2004). Specifically, product ideas characterized by a high degree of novelty - so-called radical product ideas - are often rejected at an early stage (Chesbrough, 2004) or fail in the course of the early phases of product development (Florén and Frishammar, 2012). The reasons for failure are numerous (Herrmann, 2017a). One widespread reason for the precedence of incremental product ideas over radical ones is lower risk and uncertainty (Lynn and Akgün, 1998). However, the nature of innovation has changed (Sandström and Björk, 2010). Many researchers and industry experts alike have called for more radically new innovations. Companies will require these in order to be productive and innovative in the future and ensure their long-term survival (Lecossier et al., 2019).

\section{Problem and goal}

The management of the early phases of product development, particularly idea management systems, has only changed to a limited extent despite this demand (Sandström and Björk, 2010). Consequently, companies are approaching radical innovations with the same methods. Nevertheless, these traditional methods are often more suitable for incremental rather than radical innovations (Garcia and Calantone, 2002). Therefore, many statements exist in literature claiming that radical innovation, especially in the front end, should be treated differently (Veryzer, 1998; Herrmann, 2017a). However, the warnings that 
designers should approach radical innovation differently to incremental innovations should not result in a situation where, on the one hand, only radical innovations are pursued and, on the other, existing approaches and methods are completely revised. In accordance with the numerous calls in literature for ambidexterity within companies and innovation management or product-development practice (O'Connor and Rice, 2013; Gausemeier et al., 2019), coexistence between radical and incremental innovation projects is necessary, as are methods for handling both (Sandström and Björk, 2010). In several articles, it is claimed that successful companies are "ambidextrous," (i.e., they focus on efficient handling of today's requirements [exploitation] and have to adapt to changes in their environment [exploration] at the same time) (Tushman and O'Reilly, 1996). O'Reilly and Tushman (2013) summarize the advantages of ambidexterity in companies and cite companies' sales growth, innovation ability or survival ability as examples.

The problem that this paper aims to address is the fact that ambidexterity does not play any specific role in the early phases of product development and that no distinction is therefore made between radical and incremental innovation projects (Herrmann et al., 2019b; Ahuja and Morris Lampert, 2001). However, regarding the degree of novelty, companies have to manage the front end in a way that takes account of its idiosyncratic character, especially in the case of radical development (Florén and Frishammar, 2012). In particular, the focus within this paper lies on a differentiation of ideas in the idea-management process.

The goal is to present an approach for an extended and adapted idea process model. The extension is particularly aimed at the development of radical innovations, yet it deliberately places them parallel to the process of incremental ideas. Known models and methods seem less suitable for this (Zimmer et al., 2012). The research work is thus based on promoting a balanced coexistence of radical and incremental product ideas within the idea process of product development.

Furthermore, the approach should demonstrate a supporting effect within the development of radical innovations; therefore, an initial evaluation of the presented process is required as a minimum.

In order to focus the addressed goals, the following main research questions (RQs) were defined:

1. Which deficits are apparent in known idea-process models or descriptions of activities within idea processes against the backdrop of the development of radical innovations?

2. How can the idea process be adapted in order to support the development of (radical) innovations and tackle the identified deficits?

\section{Methodological framework and procedure}

The Design Research Methodology (DRM) set out by Blessing and Chakrabarti (2009) constitutes the paper's methodological framework. Table 1 lists the four phases of DRM, their general aims, and the assignment to the paper's respective sections. Furthermore, the corresponding research questions are attributed to the DRM phases and paper's sections. A critical discussion, a conclusion (Section 7), and an outlook (Section 8) for further research follow this procedure.

Table 1. Phases of DRM and allocation of research question and section

\begin{tabular}{|c|c|c|c|}
\hline DRM phase & Goal of DRM phase & $\begin{array}{c}\text { Corresponding } \\
\text { section number }\end{array}$ & $\begin{array}{c}\text { Research } \\
\text { question }\end{array}$ \\
\hline $\begin{array}{c}\text { Research } \\
\text { clarification }\end{array}$ & $\begin{array}{c}\text { Goals: Presentation of current understanding and } \\
\text { expectations, as well as of research aims and } \\
\text { questions }\end{array}$ & $1+2$ & None \\
\hline Descriptive study I & $\begin{array}{c}\text { Understanding: Review of the literature on } \\
\text { potentially relevant topics (state of the art) + overall } \\
\text { conclusions }\end{array}$ & 4 & RQ1 \\
\hline Prescriptive study & $\begin{array}{c}\text { Support: } \text { Presentation of approaches for supporting } \\
\text { and improving the current situation }\end{array}$ & 5 & \multirow{2}{*}{ RQ2 } \\
\hline Descriptive study II & Evaluation: Evaluation of developed support & 6 & 5 \\
\hline
\end{tabular}

\section{State of the art}

This section presents an analysis of different models for idea processes. The similarities of the models and their references to the idea management of radical product ideas are identified (see Section 4.1), 
whereas Section 4.2 presents recommendations for the idea process in the context of radical product ideas and ambidexterity.

\subsection{Idea-process models}

The idea process comprises the early phases - or front end - of the product-development or innovation process and describes the management process for product ideas. Since activities in the idea process and the planning phase of the product-development process often coincide (VDI, 1980), product planning or the planning process are associated with the idea process (Pahl et al., 2007). The idea process should be systematically structured in the innovation process (Boeddrich, 2004). Therefore, many authors have introduced models for idea processes. In Table 2, 17 process models for the idea process are shown by listing their main process phases. What can be stated is that many of the models are very similar and often aligned to Cooper's (1988) well-known StageGate ${ }^{\circledR}$ process model. However, nearly all models contain implementation steps (compare the gray markings in Table 2) that go at least slightly beyond the core understanding of idea processes, or at least beyond the authors' understanding. Besides, the general term "idea" is often used within the description of the process steps. Studying the explanation of the models within the respective sources, it becomes apparent that solution ideas are frequently meant. The reference to a problem or need is therefore missing, and the product idea seems insufficiently described because a product idea characterizes the combination of a problem idea and a solution idea (Eversheim, 2003). There is rarely a subdivision into problem and solution ideas (see Herrmann et al., 2019a). Most of the described processes begin with idea generation (7 of 17). In certain models, the definition of search fields forms the first step (4 of 17). Only three processes start with the recognition or identification of a problem or opportunity. Furthermore, there is no particular distinction between radical and incremental ideas in one of the proposed models, although this is recommended elsewhere (Ahuja and Morris Lampert, 2001; Herrmann et al., 2017b). However, these recommendations are of a rather general nature. A process model especially developed for radical product ideas does not exist in literature.

Table 2. Summary of various models for idea processes

\begin{tabular}{|c|c|c|c|c|c|c|c|c|c|c|c|c|c|c|c|}
\hline \multicolumn{16}{|c|}{ Thom (1980) } \\
\hline \multicolumn{2}{|c|}{$\begin{array}{c}\text { Search-field } \\
\text { determination }\end{array}$} & \multicolumn{2}{|c|}{$\begin{array}{c}\text { Idea } \\
\text { generation }\end{array}$} & \multicolumn{2}{|c|}{$\begin{array}{c}\text { Idea } \\
\text { proposal }\end{array}$} & \multicolumn{2}{|c|}{$\begin{array}{c}\text { Testing of } \\
\text { ideas }\end{array}$} & \multicolumn{3}{|c|}{$\begin{array}{c}\text { Preparation of } \\
\text { realization plans }\end{array}$} & \multicolumn{3}{|c|}{$\begin{array}{l}\text { Decision for a plan to } \\
\text { be implemented }\end{array}$} & \multicolumn{2}{|r|}{$\begin{array}{c}\text { Idea } \\
\text { realization }\end{array}$} \\
\hline \multicolumn{16}{|c|}{ Cooper (1988) } \\
\hline \multicolumn{2}{|c|}{$\begin{array}{c}\text { Initial } \\
\text { screening } \\
+ \text { assessment } \\
\end{array}$} & \multicolumn{2}{|c|}{$\begin{array}{l}\text { Preliminary } \\
\text { assessment + } \\
\text { definition }\end{array}$} & \multicolumn{4}{|c|}{\begin{tabular}{c|c} 
Pre-development \\
business analysis + \\
development
\end{tabular}} & \multicolumn{3}{|c|}{$\begin{array}{l}\text { Pre-test review } \\
\quad+\text { testing }\end{array}$} & $\begin{array}{l}\text { Pre-trial } \\
\text { review } \\
+ \text { trial }\end{array}$ & \multicolumn{4}{|c|}{$\begin{array}{l}\text { Pre-commercialization } \\
\text { business analysis }+ \\
\text { commercialization }\end{array}$} \\
\hline \multicolumn{16}{|c|}{ Schlicksupp (1992) } \\
\hline \multicolumn{2}{|c|}{$\begin{array}{l}\text { Recognition of } \\
\text { a problem } \\
\text { or need, or } \\
\text { perception } \\
\text { of an } \\
\text { opportunity or } \\
\text { possibility } \\
\end{array}$} & \multicolumn{3}{|c|}{$\begin{array}{l}\text { Detailed analysis of } \\
\text { the issue; } \\
\text { acquisition and } \\
\text { interpretation of } \\
\text { information; } \\
\text { definition of the } \\
\text { task }\end{array}$} & \multicolumn{3}{|c|}{$\begin{array}{l}\text { Processing of the } \\
\text { task; development of } \\
\text { the solution or } \\
\text { alternative solution } \\
\text { possibilities } \\
=\text { INVENTION }\end{array}$} & \multicolumn{3}{|c|}{$\begin{array}{l}\text { Evaluation and } \\
\text { review of the } \\
\text { solution(s) found; } \\
\text { decision on } \\
\text { implementation }\end{array}$} & \multicolumn{3}{|c|}{$\begin{array}{l}\text { Implementation of } \\
\text { the solution and } \\
\text { practical use } \\
=\text { INNOVATION }\end{array}$} & \multicolumn{2}{|c|}{$\begin{array}{l}\text { Control of the } \\
\text { application } \\
\text { with regard to } \\
\text { the } \\
\text { achievement } \\
\text { of objectives }\end{array}$} \\
\hline \multicolumn{16}{|c|}{ Deschamps (1996) } \\
\hline \multicolumn{3}{|c|}{$\begin{array}{l}\text { Idea generation/idea } \\
\text { collection }\end{array}$} & \multicolumn{3}{|c|}{ Idea screening } & \multicolumn{4}{|c|}{ Idea enrichment } & \multicolumn{3}{|c|}{ Idea evaluation } & \multicolumn{3}{|c|}{ Idea classification } \\
\hline \multicolumn{16}{|c|}{ Witt (1996) } \\
\hline $\begin{array}{l}\text { Defining } \\
\text { search } \\
\text { field }\end{array}$ & \multicolumn{2}{|c|}{$\begin{array}{l}\text { Idea } \\
\text { generation }\end{array}$} & $\begin{array}{r}\text { Rol } \\
\text { dri }\end{array}$ & & \multicolumn{2}{|c|}{$\begin{array}{c}\text { Rough } \\
\text { selection with } \\
\text { aptitude } \\
\text { analysis }\end{array}$} & \multicolumn{3}{|c|}{$\begin{array}{c}\text { Precise } \\
\text { selection with } \\
\text { profitability } \\
\text { analysis }\end{array}$} & \multicolumn{3}{|c|}{$\begin{array}{l}\text { Technical development } \\
\text { + development of } \\
\text { marketing concept }\end{array}$} & $\begin{array}{r}\text { Mar } \\
\text { tes }\end{array}$ & $\begin{array}{l}\text { rket } \\
\text { sts }\end{array}$ & $\begin{array}{l}\text { Market } \\
\text { launch }\end{array}$ \\
\hline & & & & & & & hachtne & & & & & & & & \\
\hline Idea gener & tion & Idea & pturi & & $\begin{array}{r}\text { Ide } \\
\text { assessr }\end{array}$ & & $\begin{array}{l}\text { Ide: } \\
\text { prioritiz }\end{array}$ & ion & & $\begin{array}{l}\text { dea } \\
\text { ection }\end{array}$ & $\begin{array}{c}\text { Project } \\
\text { definition }\end{array}$ & $\begin{array}{r}\text { Proje } \\
\text { select }\end{array}$ & & & $\begin{array}{l}\text { Project } \\
\text { lanning }\end{array}$ \\
\hline & & & & & & & pen et a & & & & & & & & \\
\hline $\begin{array}{r}\text { Identifi } \\
\text { business }\end{array}$ & PPOI & $\begin{array}{l}\text { of a } \\
\text { tunity }\end{array}$ & & $\begin{array}{c}\text { ysis } \\
\text { op }\end{array}$ & $\begin{array}{l}\text { of the b } \\
\text { portunit }\end{array}$ & & $\begin{array}{r}\text { Idea } \\
\mathrm{m}\end{array}$ & $\begin{array}{l}\text { gene } \\
\text { laturit }\end{array}$ & & & $\begin{array}{c}\text { Idea } \\
\text { selection }\end{array}$ & & $\begin{array}{r}\text { cept an } \\
\text { devel }\end{array}$ & nd te & $\begin{array}{l}\text { chnology } \\
\text { ent }\end{array}$ \\
\hline & & & & & & & ndenbu & $\lg 1$ & & & & & & & \\
\hline Goal form & ition & $\begin{array}{c}\text { Fut } \\
\text { anal }\end{array}$ & & $\begin{array}{l}\text { Ic } \\
\text { gene }\end{array}$ & rea & $\begin{array}{l}\text { Ic } \\
\text { evalt }\end{array}$ & tion & Idea & letai & ling & $\begin{array}{l}\text { Conce } \\
\text { evaluati }\end{array}$ & & & $\begin{array}{l}\text { iplem } \\
\text { plar }\end{array}$ & $\begin{array}{l}\text { entation } \\
\text { ining }\end{array}$ \\
\hline & & & & & & & Kühn ( & 2003) & & & & & & & \\
\hline $\begin{array}{r}\text { Idea } \\
\text { generatio } \\
\text { collect }\end{array}$ & & & & & $\begin{array}{l}\text { eliminar } \\
\text { estigatic }\end{array}$ & & $\begin{array}{l}\text { recise } \\
\text { ection }\end{array}$ & & & $\begin{array}{l}\text { iled } \\
\text { gation }\end{array}$ & Final se & ection & & $\begin{array}{l}\text { Devel } \\
\text { const }\end{array}$ & $\begin{array}{l}\text { opment/ } \\
\text { ruction }\end{array}$ \\
\hline
\end{tabular}




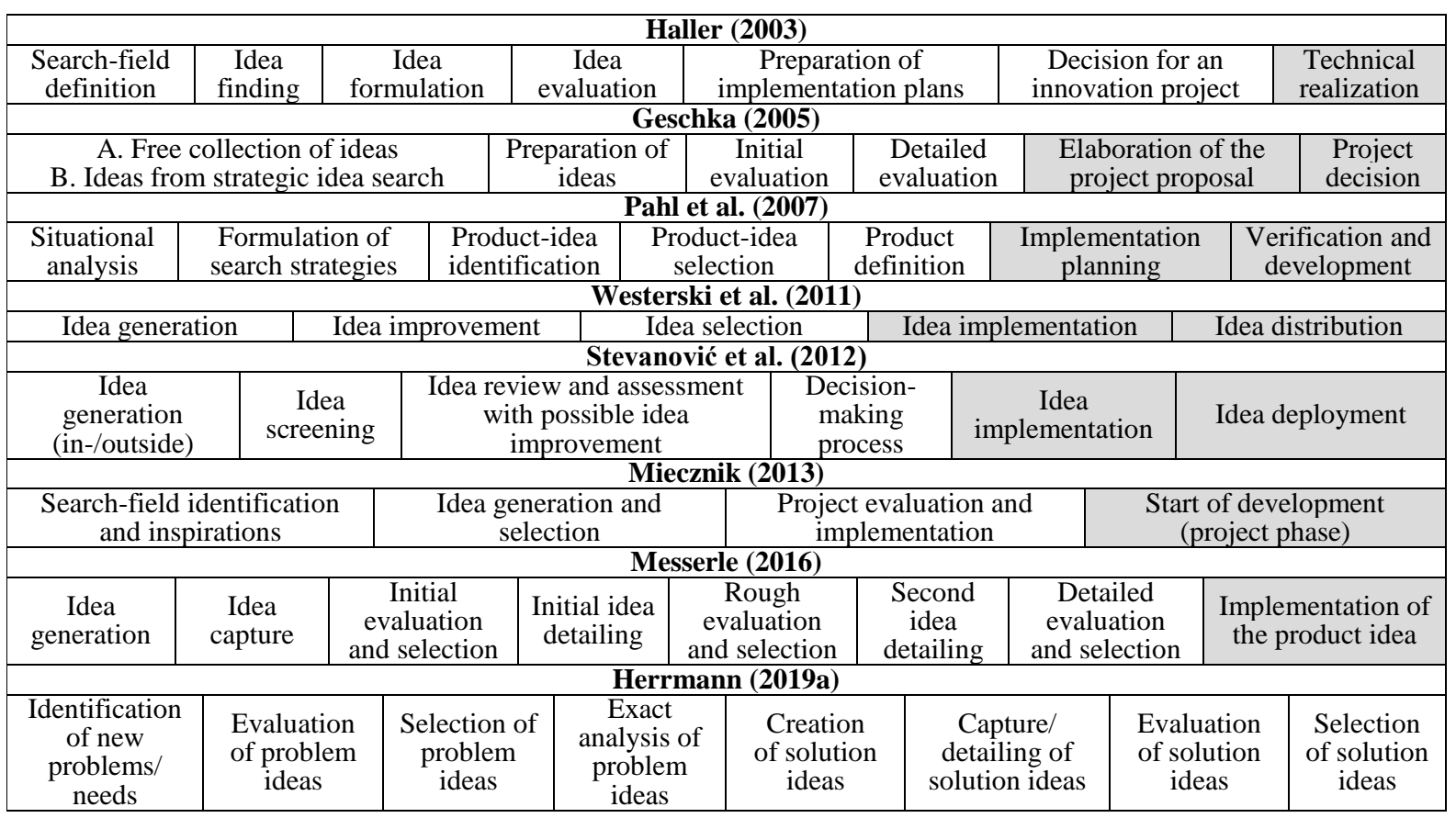

\subsection{Recommendations for idea processes in the context of radical product ideas and ambidexterity}

This section presents the results of the literature analysis, which deals with recommendations for the idea process of radical product ideas and for the context of ambidexterity. Many of the known idea-process models pursue the goal of producing continuous improvements (Boeddrich, 2004) as well as new products or ideas for innovations (Sandström and Björk, 2010). Regarding innovations that are strongly based on existing knowledge (incremental improvement), these processes can efficiently support the idea process (Verworn and Herstatt, 2007). However, these models show various disadvantages when the discussion turns to radical product ideas (Sandström and Björk, 2010). Therefore, Sandström and Björk (2010) call for more research into a dual idea-management system in which radical and incremental ideas need to be handled differently. Nevertheless, these authors warn that using a highly formulized and structured process for radical product ideas with financial criteria. They consider a dual idea process as a necessity for the successful development of radical ideas (Sandström and Björk, 2010). The idea process for these ideas should rather assume the character of a learning process (Lynn and Akgün, 1998), whereby the process should be characterized by iterative loops (Verworn and Herstatt, 2007), for example iterative tests conducted together with customers or users in order to increase adaptability, agility, and accelerating measures (Cooper, 2015). In addition, if the radical character of a radical product idea is mainly characterized by technological novelty, Cooper proposes the further development of this idea through a process preceding the actual idea process and focusing on the development of the underlying technology. From this process, product ideas can be transferred back into the standard idea process at a later point (Cooper et al., 2002). Nonetheless, all recommendations for handling and acting with regard to radical product ideas stipulate one requirement, namely the awareness of the degree of novelty: in other words, which product ideas are radical and which are incremental in nature. The fact that this status can change throughout the idea and design process endorses this statement (Herrmann et al., 2017b; Herrmann et al., 2018).

Measuring the degree of novelty makes it possible to separate innovative projects from routine activities and create a systematic innovation portfolio tailored to this classification (Hauschildt et al., 2016). Furthermore, approaches and methods can be chosen in accordance with the degree of novelty (Herrmann et al., 2018). Determining the degree of novelty plays a particularly important role in terms of technical uncertainties and the effects on innovation implementation (Pahl and Beitz, 2007).

Additionally, evaluation steps within the idea process differ since the evaluation effort for radical product ideas is higher (Breiing and Knosala, 1997). Moreover, different criteria are used when 
evaluating radical product ideas than when evaluating incremental ideas. A question arises concerning the conclusion that can be drawn from the issues collected above. To answer the first research question, it is necessary to summarize the apparent deficits in known idea process models or descriptions of activities within idea processes.

The core result is that an approach for an idea process combining the handling of incremental and radical product ideas - a so-called ambidextrous idea process - does not exist in literature. Additionally, although there are some recommendations for the handling of radical product ideas, there is often a lack of methodological recommendations to promote ambidextrous handling of radical product ideas (e.g., no differentiation in process steps), which is at least necessary for evaluation steps.

Besides that, there is a lack of a clear focus on the phases of the problem and customer needs (i.e., identification, evaluation, and selection), although Frishammar et al. (2016) emphasize that the development of radical ideas begins with the recognition of a problem or an opportunity. Few process models pay attention to these process steps, although the structured approach to the problem is considered a core aspect of design (see Brown, 2009). In the course of the uncertainties and risks associated with radical product ideas, it is the precise consideration of the need and the thorough understanding of the customer's problem that plays a significant role (Yannou, 2015).

The consideration of these aspects is only afforded limited attention in idea processes. Furthermore, the front-end literature is still vague in explaining how problems or opportunities can be identified, created, and exploited because the front-end authors seem biased towards incremental idea and concept development (Frishammar et al., 2016).

\section{Process model for an ambidextrous idea process}

In accordance with the deficits examined in Section 4, the following requirements can be derived for an ambidextrous idea process, which deals with a balanced, appropriate, and goal-oriented coexistence of radical and incremental product ideas.

The core idea of the ambidextrous idea process is to have a dual process, which needs constant measurement of the degree of novelty early on and during the process in order to monitor and assign the ideas to a compatible process path. Consequently, having a dual system for the process path requires the process steps to be designed in accordance with the idea's degree of novelty. In addition, a clear focus on the problem and therefore the problem-oriented part (generation, analysis, and evaluation of needs) of the idea process is essential, especially for radical product ideas. As such, it is necessary to modify the vocabulary used for describing the process steps, whereby a differentiation is made between the "problem idea" and "solution idea."

Figure 1 shows a generic process model for an ambidextrous idea process. Within this process model, a clear separation is presented between the problem and solution, on the one hand, and between radical and incremental ideas on the other. Assuming the ideal hypothetical situation where a company starts with a blank piece of paper, the first question is whether the strategic orientation should be on exploitation (meaning that an existing or familiar product should be incrementally improved) or on exploration (focusing on a radical innovation with a high degree of novelty compared to existing products). Knowing that this idealistic situation fails to correspond to the actual situation in companies' business contexts, a lateral entry into the process is possible, and adaption to existing business contexts and entrepreneurial starting positions is mandatory. Ideally, the process starts with the generation of new problem ideas and is followed by the systematic capture of these problem ideas. Since these steps might differ for both process paths (e.g., different generation or identification steps for problems), Figure 1 shows a separation between the two idea types. After the two initial steps irrespective of whether there are many problem ideas or only one - the first evaluation step is to be carried out. Before this, it is necessary to measure the degree of novelty in order to, firstly, adapt evaluation criteria to the degree of novelty of the problem idea (e.g., according to Herrmann et al., 2018; this is not an explicit part of this paper) and, secondly, obtain possible methodological recommendations for the further course of the process. As indicated in Figure 1, the degree of novelty can change during the course of the process, meaning that a radical idea can develop into an incremental one and vice versa. This is another reason for monitoring of the degree of novelty also 
being recommended in order to carry the idea further in the right process path with the methodological support appropriate for the idea type.

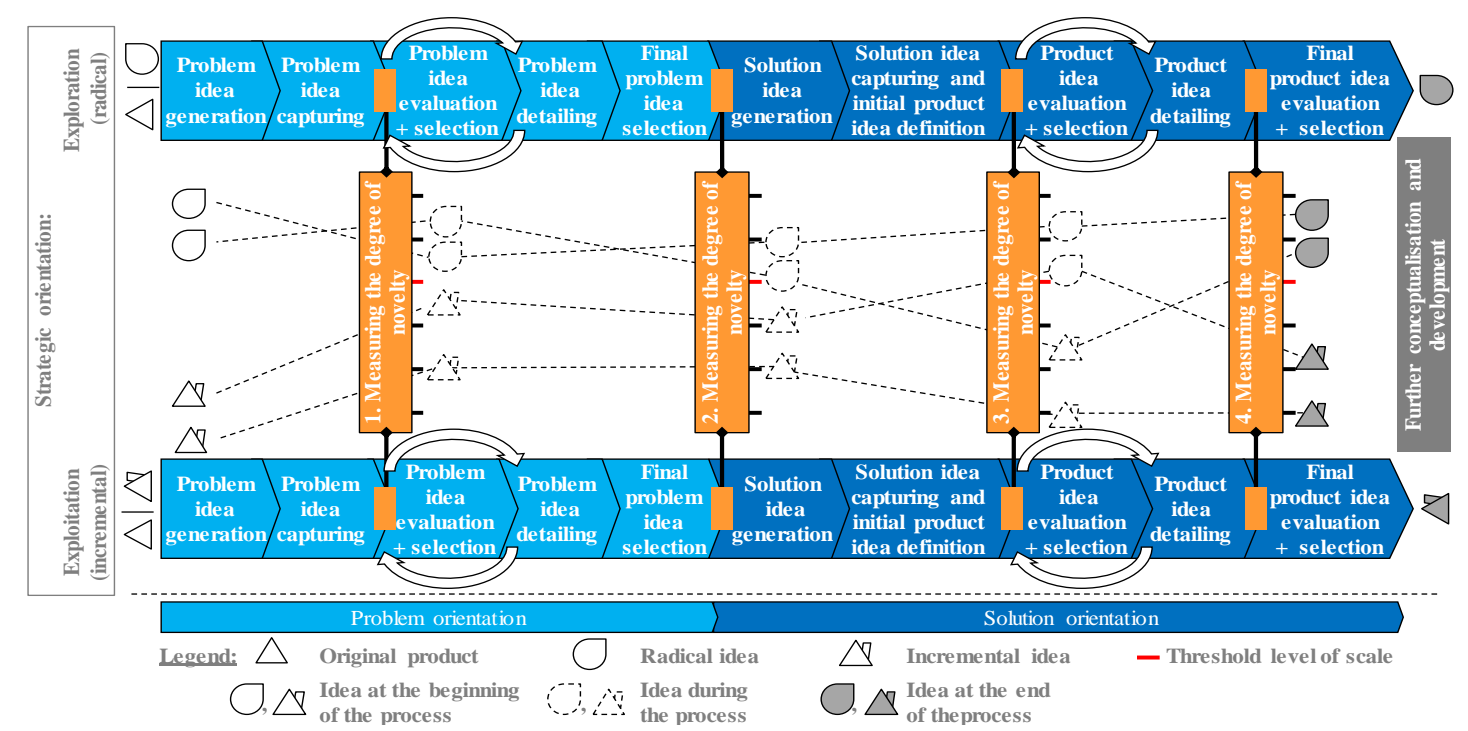

Figure 1. Generic ambidextrous idea process for radical and incremental product ideas

In consequence, the problem ideas are to be evaluated, ultimately selected, and detailed (see Figure 1), meaning that further analysis of the problem idea is appropriate. Depending on the number of problem ideas, several loops between evaluation, selection, and further detailing are recommended (white arrows in Figure 1). Further measurement of the degree of novelty might also be prudent. At the end of the problem-oriented part of the process, the final selection of the detailed and properly analyzed problem idea is needed, meaning that there can be a selection from several problem ideas or a go/no-go decision for just one problem idea. The solution-oriented part of the generic process model is similar to most of the proposed process models analyzed in Section 4, although the dualprocess path is naturally retained. As such, the generation of solution ideas is followed by a capturing step which brings together problem and solution ideas and defines an initial product idea. These ideas follow a similar evaluation and selection process featuring detailed steps to the problem idea; however, the methodological support differs, as do the evaluation and selection criteria. Two further measurement steps for determining the ideas' degree of novelty are intended. The first comes after the first product-idea capturing step, while the second comes before the final selection of the product idea. However, this number can be adapted to the development context and the company's situation. It also depends on the loops of evaluation, selection, and detailing in between. Although Figure 1 shows that the entire process path and the steps of both paths are equal in length, it must be noted that the time horizon for radical innovations and product ideas might be much longer and much more detailed than for incremental ones due to the higher risk and uncertainty inherent in the development effort. Therefore, further steps such as measurements of the degree of novelty or detailing/evaluation loops might be prudent. The last step of the process is the final selection of product ideas for further conceptualisation and development.

In recent years, the authors' institute has produced numerous recommendations for the imple mentation of the different process steps described above and depicted in Figure 1: These are listed in Table 3 with further details of the respective publication.

Some process steps are similar within the two process paths for radical and incremental ideas (see Table 3), although some steps differ dramatically. Therefore, the steps for radical ideas constitute the particular focus of the authors' current research. Further investigations and scientific publications of results are anticipated for the future. Since the detailing step for radical product ideas is of particular interest, a catalogue of methods was developed that - depending on the degree of radical novelty - gives special recommendations for the further detailing of the idea. This was compiled by means of expert interviews and recommendations from literature. 
Table 3. Description of the process steps of the generic ambidextrous idea process

\begin{tabular}{|c|c|}
\hline $\begin{array}{l}\text { Problem-idea } \\
\text { generation }\end{array}$ & $\begin{array}{l}\text { Generation of new problem fields or search fields. Possible support can be provided by the "emoji } \\
\text { method," for example (Herrmann et al., 2019a). }\end{array}$ \\
\hline $\begin{array}{l}\text { Problem-idea } \\
\text { capture }\end{array}$ & $\begin{array}{l}\text { In order to capture and analyze the product idea, the problem-idea profile can be used (Herrmann et al., } \\
2017 \mathrm{c}) \text {. Brandenburg }(2002) \text { describes the comprehension of the idea as a "concise description," which } \\
\text { contains both aspects of the problem and solution ideas. The information of the problem analysis can thus } \\
\text { be used as a basis for further steps. }\end{array}$ \\
\hline $\begin{array}{l}\text { Problem-idea } \\
\text { evaluation }+ \\
\text { selection }\end{array}$ & $\begin{array}{l}\text { For the evaluation and selection of ideas - mainly product ideas - numerous methods exist (Messerle, } \\
\text { 2016); a method for the evaluation of problem ideas requires special criteria which are adapted to this very } \\
\text { early and abstract phase (the examination of such criteria forms part of the authors' current research). }\end{array}$ \\
\hline $\begin{array}{l}\text { Problem-idea } \\
\text { detailing }\end{array}$ & $\begin{array}{l}\text { Steps detailing and analyzing the problem idea by adding further aspects of the problem. Various methods } \\
\text { are known and can be adopted from design thinking or quality management (see Herrmann et al., 2016). }\end{array}$ \\
\hline $\begin{array}{l}\text { Solution-idea } \\
\text { generation }\end{array}$ & $\begin{array}{l}\text { The generation of new solution ideas is often associated with creative techniques (Schlicksupp, 1992). } \\
\text { Recommendations for these methods are numerous, whereby methods are differentiated according to the } \\
\text { desired result's degree of novelty. }\end{array}$ \\
\hline $\begin{array}{l}\text { Product-idea } \\
\text { evaluation }+ \\
\text { selection }\end{array}$ & $\begin{array}{l}\text { As mentioned above, methods and criteria for idea evaluation are numerous. A sample system for } \\
\text { evaluating product ideas is presented by Messerle (2016); however, it is mostly appropriate for incremental } \\
\text { ideas. The appropriate evaluation of radical product ideas is part of actual research by the authors. }\end{array}$ \\
\hline $\begin{array}{l}\text { Product-idea } \\
\text { detailing }\end{array}$ & $\begin{array}{l}\text { This process step is different for incremental and radical ideas. Incremental ideas can mostly work with } \\
\text { methods for further information procurement, while radical ideas need different and specific } \\
\text { methodological support. This forms part of the authors' current research. }\end{array}$ \\
\hline $\begin{array}{l}\text { Measuring } \\
\text { the degree of } \\
\text { novelty }\end{array}$ & $\begin{array}{l}\text { Early papers of the authors (Herrmann et al., } 2017 \mathrm{~b} \text {; Herrmann et al., 2018) have dealt with this step. The } \\
\text { measurement should always consider the degree of novelty within the four dimensions "market," } \\
\text { "customer," "technology," and "company organization." }\end{array}$ \\
\hline
\end{tabular}

Table 4 presents a brief extract of the most important methods. This catalogue is still under development and will be subjected to ongoing tests. The table should therefore show the conceptual idea behind the methodology. The table was subdivided in accordance with the four dimensions of "market," "customer," "technology," and "company organization" (see Herrmann et al., 2018). It lists suggestions for methods, indicating whether there is a radical degree of novelty for the respective dimension.

Table 4. Extract of recommendation actions regarding a radical degree of novelty

\begin{tabular}{|c|c|c|c|c|}
\hline $\begin{array}{l}\text { Radical for } \\
\ldots\end{array}$ & $\begin{array}{l}\text { Market (potential for } \\
\text { market change) }\end{array}$ & $\begin{array}{l}\text { Customer/user } \\
\text { (perception) }\end{array}$ & $\begin{array}{l}\text { Designer/product developer } \\
\text { (technology) }\end{array}$ & $\begin{array}{l}\text { Company } \\
\text { (organization) }\end{array}$ \\
\hline 1. Measuring & $\begin{array}{l}\text { - Market research } \\
\text { - First survey } \\
\text { - Trend analysis and } \\
\text { monitoring }\end{array}$ & $\begin{array}{l}\text { - } \text { Define pain points } \\
\text { - Observe whole } \\
\text { customer journey }\end{array}$ & $\begin{array}{l}\text { - Lead-user workshop Design } \\
\text { Thinking phases } \\
\text { "understand"/"observe" } \\
\text { - Self-tests }\end{array}$ & $\begin{array}{l}\text { - } \text { Promote project } \\
\text { - Build up/include } \\
\text { expert knowledge }\end{array}$ \\
\hline 2. Measuring & $\begin{array}{l}\text { - Systematic market } \\
\text { monitoring and scanning } \\
\text { - Initial marketing } \\
\text { concept }\end{array}$ & $\begin{array}{l}\text { - Lead-user survey } \\
\text { - Scenario technique } \\
\text { - Cyber- } \\
\text { ethnography }\end{array}$ & $\begin{array}{l}\text { - Creative techniques (e.g., TRIZ) } \\
\text { - Design Thinking, phase "ideate" } \\
\text { - UX-driven idea-generation } \\
\text { methodology }\end{array}$ & $\begin{array}{l}\text { - } \text { Consider co-ops } \\
\text { (universities, start-ups) } \\
\text { - Cross industry projects }\end{array}$ \\
\hline 3. Measuring & $\begin{array}{l}\text { - "Blue ocean" method } \\
\text { - Patent analysis } \\
\text { - Consider the launching } \\
\text { guidelines for radical } \\
\text { innovations }\end{array}$ & $\begin{array}{l}\text { - Define must-haves } \\
\text { - Customer surveys } \\
\text { - Check need } \\
\text { fulfilment }\end{array}$ & $\begin{array}{l}\text { - Include external experts } \\
\text { - Design Thinking phases } \\
\text { "prototype"/“test" } \\
\text { - Include early adopters }\end{array}$ & 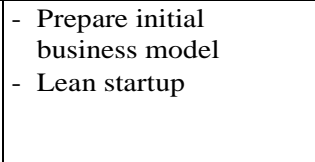 \\
\hline 4. Measuring & $\begin{array}{l}\text { - Define unique selling } \\
\text { points } \\
\text { - Define target market }\end{array}$ & $\begin{array}{l}\text { - Conduct field tests } \\
\text { - Co-creation }\end{array}$ & $\begin{array}{l}\text { - Concretize requirements } \\
\text { - Show feasibility }\end{array}$ & $\begin{array}{l}\text { - Prepare project } \\
\text { planning }\end{array}$ \\
\hline
\end{tabular}

\section{Evaluation}

A systematic presentation to experts and a use case were carried out in order to evaluate the developed process and its support value. The generic ambidextrous idea process was presented to 16 experts from various German companies, mostly working in the fields of innovation management and product development, or on their company's board of management. All information and explanation regarding the 
process itself, the process steps, the supporting methods within the process - for example, the measurement of the degree of novelty - and the idea of the catalogue of supporting methods for detailing an idea further were introduced in a two-hour session, after which all experts were able to ask questions. Additionally, a brief test scenario representing an example for a project passing the process was presented, starting from the very beginning of the process and continuing through to the defined product idea. The experts were then asked for feedback, using a questionnaire. The question of whether the process could satisfy the need for support with radical product ideas was largely affirmed. Moreover, the experts were keen to emphasize the usefulness of the constant measurement of the degree of novelty, and thus of the review, as helpful steps to be derived from the recommendations for action. Additionally, the radical product ideas get more attention. Although, some of the experts warn that the process of ideas could become too complex, they underline the different handling of the ideas.

The second scenario considers a realistic product-development assignment within a medium-sized company in Germany. The team of six pre-development product developers went through the process, although they started with the capture and analysis of the problem idea since the initial problem idea was already given. The product idea appeared incremental during the first measurement of the degree of novelty. However, upon further analysis, this changed as individual dimensions (e.g., the designing team and the company organization) were regarded as radical and further risks and uncertainties were discovered that the team had underestimated. With the generation and evaluation of several solution ideas, the most diverse product ideas were defined, whose degrees of novelty were partly radical and partly incremental, meaning that the dimensions representing a radical degree of novelty differed. At the time of this paper's submission, the project progress was just before the final definition of the product idea for further development, with the final evaluation and detailing steps still lacking. The team was regularly provided with information on the process, the methods, and the catalogue of recommendations depending on the degree of novelty. A survey of the team with the current status of the project was also carried out within this scenario. The feedback was predominantly positive, and the supporting effect was confirmed. The need for differentiation of idea types regarding the degree of novelty was granted. According to the expert team, the monitoring of the degree of novelty is helpful because obstacles, risks, and uncertainties are recognized early on and the in-depth confrontation of these aspects makes it less likely to underestimate them. Additionally, critical reviews are encouraged, while recommendations for action provide a direct springboard for actions and appropriate countermeasures.

\section{Discussion and conclusion}

Evidence of whether or not the two research questions were answered should be provided for a discussion of the paper's results. The goal was to analyze idea-process models pertaining to the development of radical product ideas and the performance of ambidexterity in idea management. An ambidextrous idea process is only described in literature in a descriptive way. To name one example, the broad analysis of known models showed that idea processes do not take into account a differentiation between radical and incremental ideas, a necessary differentiation between the problem idea and solution idea, or the core idea of ambidexterity. Therefore, requirements were derived regarding the various deficits found in literature. Based on these requirements, a new process model was developed. This included a systematic procedure for both idea types and methodical recommendations based on the degree of novelty. Additionally, the process was divided into a problem- and a solution-oriented process part. In the age of saturated markets and incremental development of solutions, the designers' and product developers' way of thinking should be broadened by discovering and analyzing new problems and requirements first before searching for solutions in a structured way based on these. The process was tested within two different scenarios, and the supporting potential of the process was initially confirmed. However, the process model must be applied in further scenarios. It must be ensured that the chosen measurement steps for the degree of novelty are appropriate for the period of time within the process. In Figure 1, these were proposed in line with the authors' process experience.

\section{Outlook}

To expand upon the initial evaluation activities, different scenarios in different companies (i.e., different design contexts) are necessary to confirm the supporting effect of the process model completely. In this 
context, the various supporting items (methods, catalogues, etc.) have to be evaluated as well. However, the focus should be on the overall process and the associated process interfaces, as some previous papers (e.g., Herrmann et al., 2018) have already outlined the effective support of individual methods.

\section{References}

Ahuja, G. and Morris Lampert, C. (2001), "Entrepreneurship in the large corporation. A longitudinal study of how established firms create breakthrough inventions", Strategic Management Journal, Vol. 22 No. 6, pp. 521-543. https://doi.org/10.1002/smj.176

Blessing, L.T.M. and Chakrabarti, A. (2009), DRM, a Design Research Methodology, Springer, London.

Boeddrich, H.-J. (2004), "Ideas in the Workplace: A New Approach Towards Organizing the Fuzzy Front End of the Innovation Process", Creativity and Innovation Management, Vol. 13 No. 4, pp. 274-285.

Brandenburg, F. (2002), Methodik zur Planung technologischer Produktinnovationen, Shaker, Aachen.

Breiing, A. and Knosala, R. (1997), Bewerten technischer Systeme: Theoretische und methodische Grundlagen bewertungstechnischer Entscheidungshilfen, Springer, Berlin.

Brown, T. (2009), Change by design: How design thinking transforms organizations and inspires innovation, Harper Collins, New York.

Chesbrough, H. (2004), "Managing Open Innovation”, Research-Technology Management, Vol. 47 No. 1, pp. 23-26. https://doi.org/10.1080/08956308.2004.11671604

Cooper, R.G. (1988), "The new product process: A decision guide for management", Journal of Marketing Management, Vol. 3 No. 3, pp. 238-255. https://doi.org/10.1080/0267257X.1988.9964044

Cooper, R.G. (2015), The Latest View: The Stage-Gate ${ }^{\circledR}$ System for New-Product Development, [online] Product Development Institute Inc. Available at: https:/www.bobcooper.ca/images/files/articles/2/2-2-The-LatestView-on-Stage-Gate.pdf (accessed 04.09.2019)

Cooper, R.G., Edgett, S.J. and Kleinschmidt, E.J. (2002), "Optimizing the Stage-Gate Process. What BestPractice Companies are Doing”, Research-Technology Management, Vol. 45 No. 6, pp. 43-49. https://doi.org/10.1080/08956308.2002.11671518

Eversheim, W. et al. (2003), "Die InnovationsRoadmap-Methodik", In: Eversheim, W. (Ed.), Innovationsmanagement für technische Produkte: Mit Fallbeispielen, Engineering online library, Springer, Berlin, Heidelberg, pp. 27-131.

Florén, H. and Frishammar, J. (2012), "From Preliminary Ideas to Corroborated Product Definitions: Managing the Front End of New Product Development", California Management Review, Vol. 54 No. 4, pp. 20-43. https://doi.org/10.1525/cmr.2012.54.4.20

Frishammar, J. et al. (2016), "The Front End of Radical Innovation. A Case Study of Idea and Concept Development at Prime Group", Creativity and innovation management, Vol. 25 No. 2, pp. 179-198. https://doi.org/10.1111/caim.12175

Garcia, R. and Calantone, R. (2002), "A critical look at technological innovation typology and innovativeness terminology. A literature review”, Journal of Product Innovation Management, Vol. 19 No. 2, pp. 110-132. https://doi.org/10.1111/1540-5885.1920110

Gausemeier, J. et al. (2019), Innovationen für die Märkte von morgen, Hanser, München. https://doi.org/ $10.3139 / 9783446429727$

Gerstbach, I. (2018), 77 Tools für Design Thinker. Whitebooks, 2. edition, GABAL Verlag, Offenbach.

Geschka, H. (2005), "Ideenmanagement - Grundlage für einen dauerhaften erfolgreichen Innovationsfluss", Industrie Management, Vol. 21 No. 3, pp. 29-32.

Haller, C. (2003), Verhaltenstheoretischer Ansatz für ein Management von Innovationsprozessen [PhD Thesis], Fakultät Wirtschaft- und Sozialwissenschaften, University of Stuttgart, 2003.

Hauschildt, J. et al. (2016), Innovationsmanagement, Vahlen, München.

Herrmann, T., Binz, H. and Roth, D. (2017a), "Forschungsbedarf und erste Lösungsansätze im Umgang mit radikalen Innovationen im Kontext heutiger Produktentwicklungsprozesse", In: Binz, H., Bertsche, B., Bauer, W. and Roth, D. (Eds.), 4. Stuttgarter Symposium für Produktentwicklung (SSP), Stuttgart, pp. 1-10.

Herrmann, T., Binz, H. and Roth, D. (2017b), "Necessary extension of conventional idea processes by means of a method for the identification of radical product ideas", in Proceedings of ICED 2017 / 21 st International Conference on Engineering Design, Aug. 21-25, 2019, The Design Society, Vancouver, Canada, pp. 79-88.

Herrmann, T., Binz, H. and Roth, D. (2017c), "Tool for creating a defined task as preparation for a targetoriented idea generation process", Proceedings of ICED 2017 / 21st International Conference on Engineering Design, Aug. 21-25, 2019, The Design Society, Vancouver, Canada, pp. 119-128.

Herrmann, T. et al. (2019a), "The Emoji Method: An Approach for Identifying and Formulating Problem Ideas", in Proceedings of IRC / International Research Conference, Jan. 24-25, 2019, World Academy of Science, Engineering and Technology, Paris, pp. 1351-1366. 
Herrmann, T., Roth, D. and Binz, H. (2018), “Approach for Identifying and Initially Assessing Radical Product Ideas", in Proceedings ICE/IEEE ITMC 2018 / International Conference on Engineering, Technology and Innovation (ICE/ITMC) Stuttgart, June 17-2, 2018, IEEE, Piscataway, NJ, pp. 1-9.

Herrmann, T., Roth, D. and Binz, H. (2019b), "Radikale Innovationen im Ideenmanagement. Eine empirische Erhebung zum Verständnis und zur Bedeutung von und zum Umgang mit radikalen Produktideen”, Ideenund Innovationsmanagement, Vol. 45 No. 03, pp. 80-88.

Koen, P. et al. (2001), "Providing clarity and a common language to the 'Fuzzy Front End", Research Technology Management, Vol. 44 No. 2, pp. 46-55. https://doi.org/10.1080/08956308.2001.11671418

Kühn, A. (2003), Systematik des Ideenmanagements im Produktentstehungsprozess, Verlagsschriftenreihe Heinz-Nixdorf-Institut, Universität Paderborn, Bd. 130, HNI, Paderborn.

Lecossier, A. et al. (2019), "A New Approach Dedicated to the Continuous Assessment and Improvement of a Radical Innovation Capacity within a Mature Company", in Proceedings ICE/IEEE ITMC 2018 / International Conference on Engineering, Technology and Innovation (ICE/ITMC) Stuttgart, June 17-2, 2018, IEEE, Piscataway, NJ, pp.1-6.

Lynn, G.S. and Akgün, A.E. (1998), "Innovation Strategies under Uncertainty: A Contingency Approach for New Product Devz`elopment”, Engineering Management Journal, Vol. 10 No. 3, pp. 11-18.

Messerle, M., Binz, H. and Roth, D. (2012), "Existing problems of idea evaluations and possible areas of improvement", in Proceedings of the DESIGN Conference / 12th International Design Conference, Dubrovnik, Croatia, May 21-24, 2012. The Design Society, pp. 1917-1928.

Miecznik, B. (2013), "Ideenmanagement", in Abele, T. (Ed.), Suchfeldbestimmung und Ideenbewertung, Springer Gabler, Wiesbaden, pp. 143-168.

O'Connor, G.C. and Rice, M.P. (2013), "A Comprehensive Model of Uncertainty Associated with Radical Innovation", Journal of Product Innovation Management, Vol. 30, pp. 2-18. https://doi.org/10.1111/jpim.12060

O’Reilly, C.A. and Tushman, M.L. (2013), "Organizational Ambidexterity: Past, Present, and Future”, Academy of Management Perspectives, Vol. 27 No. 4, pp. 324-338. https://doi.org/10.5465/amp.2013.0025

Pahl, G. et al. (2007), Engineering Design: A Systematic Approach, Third Edition, Springer-Verlag London Limited, London.

Sandström, C. and Björk, J. (2010), "Idea management systems for a changing innovation landscape", International Journal of Product Development, Vol. 11 No. 3/4, pp. 310-324. https://doi.org/10.1504/ IJPD.2010.033964

Schachtner, K. (1999), "Kommunikations- und Informationsstrukturen für die Planung marktgerechter Produktinnovationen”, Information Management \& Consulting, Vol. 14 No. 3, pp. 81-89.

Schlicksupp, H. (1992), Innovation, Kreativität und Ideenfindung, Vogel-Fachbuch, 4. edition, Vogel, Würzburg.

Stevanović, M., Marjanović, D. and Štorga, M. (2012), "Decision support system for idea selection", Proceedings of the DESIGN Conference / 12th International Design Conference, Dubrovnik, Croatia, May 21-24, The Design Society, 2012, pp. 1951-1960.

Thom, N. (1980), Grundlagen des betrieblichen Innovationsmanagements, 2. edition, Hanstein, Königstein/Ts.

Tushman, M.L. and O'Reilly, C.A. (1996), "Ambidextrous Organizations: Managing Evolutionary and Revolutionary Change”, California Management Review, Vol. 38 No. 4, pp. 8-29. https://doi.org/10.2307/ 41165852

VDI (1980), VDI Richtlinie 2220:1980: Produktplanung - Ablauf, Begriffe und Organisation, Verein Deutscher Ingenieure, Beuth, Berlin.

Verworn, B. and Herstatt, C. (2007), "Strukturierung und Gestaltung der frühen Phasen des Innovations prozesses”, In: Herstatt, C. and Verworn, B. (Eds.), Management der frühen Innovationsphasen, Gabler, Wiesbaden, pp. 111-134.

Veryzer, R.W. (1998), "Discontinuous Innovation and the New Product Development Process", Journal of Product Innovation Management, Vol. 15 No. 4, pp. 304-321. https://doi.org/10.1111/1540-5885.1540304

Westerski, A., Iglesias, C.A. and Nagle, T. (2011), "The road from community ideas to organisational innovation: a life cycle survey of idea management systems", International Journal of Web Based Communities, Vol. 7 No. 4, pp. 493-506. https://doi.org/10.1504/IJWBC.2011.042993

Witt, J. (1996), "Grundlagen für die Entwicklung und Vermarktung neuer Produkte. Überblick über den Ablauf des Innovationsprozesses", In Witt, J. (Ed.), Produktinnovation: Entwicklung und Vermarktung neuer Produkte, Vahlen, München, pp. 1-110.

Yannou, B. (2015), "Supporting need seeker innovation: the Radical Innovation Design methodology", Proceedings of ICED 2015 / 20th International Conference on Engineering Design, July 27-30, 2015, The Design Society, Milano, Italy, pp. 51-60.

Zimmer, B., Yannou, B. and Stal, J. (2012), "Proposal of a Radical Innovation Project Selection Model based on Proofs of Value, Innovation, and Concept", Proceedings of the DESIGN Conference / 12th International Design Conference, Dubrovnik, Croatia, May 21-24, 2012. The Design Society, pp. 141-150. 